\section{Textbook of Dendrology}

W.M. Harlow, E.S. Harrar, J.W. Hardin and F.M. White. Eighth Edition. 534 pp. McGraw-Hill, New York.

McGraw-Hill's venerable Textbook of Dendrology is back. But not better than ever, I fear. Don't let the exquisite cover photograph fool you.

Edition eight has followed seven in only five years. It re-arranges the order of the chapters not directly concerned with identification and description of particular species, adds good dichotomous keys and also a pronunciation guide. The latter is just as well, since the seventh edition followed the pack and subsumed most of Taxodiaceae into Cupressaceae (they sure look different to me), on the basis of rabbits' immunilogical responses; I can't get my tongue around the rejected Sciadoptyaceae. New diagrams of morphological features are added, and while serving their purpose, do not, as botanical illustrations can, leap out of the page at you (such as those in Gilkey and Pachard's 1962 "Winter Twigs" and those in some other tree books do).

Earlier editions of this text had shown a welcome trend, not it seems continuing, of including more information on how trees grow. Surely dendrology in the North American sense is sterile and almost unteachable. In the European sense of the word, it means how trees look, and how they get to look that way, with form and function illuminating each other. This text had looked like becoming 'real' dendrology, but instead has taken another route, making too many genuflections to currently fashionable topics (often North Carolina centric) and to political correctness.

No doubt none of this carping is of any consequence; the book is fine scientifically. However, this reviewer has been teaching dendrology since the mid-pleistocene, and consequently is aware that most of the photographs in the book date from approximately that era. They look very tired: and some, such as those showing cones of incense-cedar, western redcedar and western larch are still upside down! Younger people won't mind or notice. But they will mind that the photographs have been reproduced by some digital wizardry that makes them appear to have been printed on blotting paper. They are just not good enough.

Farrar has recently revised Native Trees of Canada, and transformed it into Trees in Canada. It's marvellous. If you need a dendrology (North American sense) book, get it. For a tree growth book, you're out of luck. The good one, Büsgen and Münch, is about seventy years old. Someone please up-date it.

\section{John Worrall, Forestry, UBC}

\section{L'Inde du Sud}

Pascal Gauthier et Gérard Bourgeon (rédacteurs) 1996. Dossiers de foresterie internationale, $n^{\circ} 7$, Département des sciences du bois et de la forêt, Faculté de foresterie et de géomatique, Université Laval, Québec (Québec) G1K 7P4, 48 p., 8 tableaux, 10 figures, 71 références, couverture souple, $21 ¥ 27 \mathrm{~cm}$, ISBN 29803658-1-3, prix \$6.95 plus les taxes et les frais d'envoi.

Le dossier de foresterie internationale portant sur l'Inde du Sud a été rédigé à la suite d'un stage en Inde, effectué en mars 1994 par les étudiants de la Faculté de foresterie et de géomatique de l'Université Laval à Québec, sous la direction du professeur M.M. Grandtner. L'étude concerne les États de l'Andra Pradesh, du Karnataka, du Kérala, du Tamil Nadu ainsi que les Territoires de l'Union: le Pondichéry et le Goa.

Le document est clair, conci et bien présenté. Il est divisé en quatre grandes parties traitant du cadre écologique, de la végétation forestière, de la foresterie indienne et de l'utilisation secondaire de la forêt. Le tout est appuyé par plusieurs tableaux et illustré de figures.

Les descriptions géographique, géomorphologique, climatique (tenant compte du rôle majeur de la mousson) et pédologique permettent de bien comprendre la distribution de la végétation et aussi la pression qu'exerce la population sur cette dernière au profit de l'agriculture. Les différents types de forêt sont bien analysés et classifiés selon l'altitude et la latitude. On traite d'abord des mangroves et du rôle écologique majeur qu'elles jouent en tant qu'écosystème côtier. Une importante analyse des forêts sempervirentes, réparties en plusieurs types et faciès, est ensuite présentée. Une brève description fait état des types forestiers d'altitude et de la forêt tropicale semi-sempervirente humide qui occupent toutefois une faible portion du territoire. On fait aussi mention de la forêt tropicale décidue humide et des types de forêt tropicale sèche, victimes de surexploitation, en partie à cause des essences qui les composent: le teck et le santal. La forêt plantée occupe une large place sur le territoire. Elle a pour but de réduire la pression anthropique sur les forêts naturelles et d'augmenter la productivité des friches. Ce sont surtout des plantations de teck, d'eucalyptus et d'acacia.

Le chapitre sur la foresterie indienne traite du contexte actuel et de la pénurie des produits forestiers face à l'augmentation de la population. De plus, on voit comment cette démographie galopante exerce des pressions considérables sur l'écosystème forestier (bois de chauffe, agriculture, dégradation...). On y décrit l'aménagement et la sylviculture des forêts tropicales, notamment du teck ainsi que de diverses plantations. Un volet intéressant sur l'exploitation forestière montre la faible mécanisation et la faible productivité des opérations dues, entre autres, au contexte social (chômage, surabondance de la main d'oeuvre). $\mathrm{Ce}$ volet est suivi d'une partie sur la transformation du bois où l'on voit que cette dernière est relativement limitée et peu tournée vers les marchés internationaux sauf pour les bois de teck et de santal. L'utilisation secondaire de la forêt est un aspect important de ce dossier. On y traite, entre autres, des produits non ligneux qui sont surtout l'apanage des plantations (latex, huiles essentielles, plantes médicinales ...). Le commerce du bois, pour sa part, est décrit comme un système très complex à cause d'une lourdeur et d'une inertie administrative probablement inégalée dans le reste du monde.

Le texte souligne aussi l'importance du rôle des femmes dans la foresterie indienne. Une forte proportion de celles-ci travaillent dans le secteur forestier, particulièrement dans la récolte du bois de chauffe. Aussi, elles sont très concernées par les problèmes de déforestation. L'agroforesterie est d'une importance capitale dans ce pays et de ce fait, de nombreux projets misent sur l'apport des 
femmes pour voir aboutir leur réalisation. Les programmes d'aide au développement son offerts par différents organismes dont l'ACDI et les ONG. Un volet intéressant explique en détail le système agrosylvicultural. L'ouvrage se termine par une partie traitant de la destruction des forêts (les causes) et des politiques de conservation pour y remédier (réserves, parcs...), politiques qui semblent précaires face à l'accroissement de la population et à la pression qu'elle exerce sur la forêt. L'Inde doit désormais faire des choix judicieux et miser sur le principe qui a permis son développement: la foresterie sociale.

\section{J.-C. Tissaux}

\section{Forest Management in Canada}

Monique M. Ross. 1995. Canadian Institute of Resources Law, University of Calgary, Calgary, $A B$.

This book could well be described as containing an in-depth study of the political and legal "environment" of forest use in Canada today.

The stated goal of the book set out in the Forward is inter alia:

"We hope (it) will be of use not only to those in the legal profession, but more generally ..."

Just as the Charter of Rights has imposed upon the judiciary the necessity of making broad social value decisions, Forest Management in Canada describes in detail the current broad "multiple use" concepts affecting our forest use today. All users of the forest including lawyers who represent their various interests, must be aware of these concepts. The conflicting claims of the commercial forest industry, recreational users, environmentalists and aboriginal users are described in some detail making this book mandatory reading. The environmental assessment legislation requires a broad perspective in order for an advocate to properly present his client's position.

Since governments play such a dominant roll in our forest management, "political" awareness is crucial for anyone dealing in this area. A good part of the book is directed at a review and understanding of this fact. An insight into current and future policies together with agencies and personnel affecting those policies is provided.
A great deal of the book is devoted to "the legal framework of forest management" and includes a list of leading cases and statues.

There is a major criticism however of this book so far as it aspires to be a legal reference tool. There is no index. In addition the case law and statutes are not cross-referenced. For example the landmark case of Regina $v$. Sparrow is cited in the Table of Cases but is neither indexed nor cross-referenced with the text. In fact, it is found at page 103 as Footnote 103 (just to add a little confusion) and is referred to simply as "The Sparrow decision on traditional rights ..." - what traditional rights? What key points did the Supreme Court of Canada make in its decision? One will have to go elsewhere to obtain this information.

The book does contain an extensive and illustrative Table of Contents but this does not fully answer the criticism of a lack of index.

In conclusion, Forest Management in Canada contains a great deal of information of value to a lawyer or to anyone else seeking to understand the legal and policy intricacies of the Canadian forest industry both presently and in the future. The lack of an index hinders easy access to this information.

I would give the book $\mathrm{A}+$ for content and organisation and D- for lack of inclusion of the practical tools required for quick access.

Reviewed by The Honourable Mr. Justice Frank K. Roberts Ontario Court of Justice (General Division) (Former Director Algonquin Forestry Authority 1975-86)

Feasibility of Establishing a Lumberman's Museum in the National Capital and An overview of $\mathbf{2 0 0}$ years of Lumbering and Forestry in the Ottawa Valley

John D. Dunfield. 1996. Published by the author, Apt. 805, 2625 Regina St. Ottawa, ON. K2B 5W8. $\$ 20.00+S \& H, 160$ pp.

From 1993 to 1995 John Dunfield investigated the possibility of establishing a lumberman's museum in the Ottawa/Hull region. From his travels and research, mostly in the upper Ottawa Valley, he gathered information about existing artifacts, present and potential museums, and other references on the historical development of the forest industry in the Ottawa river watershed during the period 1800-1950. A major lumberman's museum in Canada's capital region is still a dream to be realized, but his research documents information which will help future efforts in this regard. In so doing, it portrays a broad outline of this colourful period of early forest history in the Ottawa Valley and is a useful guide for anyone studying it.

Most old white and red pine forests have gone from the Ottawa Valley, except for a few pockets which have survived human and natural forces. The author describes some of these. Equally scattered is actual evidence on the ground or waterways of early logging or mill operations. The author pictures a number of surviving buildings or aging structures throughout the region or in local museums. Old photographs show others which have long since disappeared.

Many artifacts still exist in private collections and local museums or buried away in storage of national museums waiting for the creation of a fitting showcase. Rich in history are these tools and equipment of the old-time logger and sawmiller, and rich, too, in nomenclature. Modern terminology cannot match terms like chickadee, crazy wheel, deacon seat, go-devil, muzzle loader and alligator. Lumberjack Glossaries are included to help enlighten the younger reader of this book on their meanings.

The author gives consideration to some possible locations for a lumberman's museum. Reference is also made to related studies by others and to factors which would have a bearing on support for such as project.

Over 160 illustrations, many of which are photographs taken by the author, form a major part of the $81 / 2$ by 11 inch format. The photos are black and white and clearly picture the artifacts, equipment, local museums, structures and other subjects of interest to the historian.

This book will be useful to those who are interested in logging and lumbering in the Ottawa Valley in the nineteenth and first half of the twentieth century. It can serve as a guide to local museums, old logging and milling sites, or stately homes built by lumber barons. Those continuing to promote a lumberman's museum in the National Capital region will find this book helpful for locating artifacts, documents and historical references and for investigating potential support and location for it.

A.D. (Dal) Hall 
Reap Without Sowing: Wild Food from Nature's Cornucopia

Erika E. Gaertner, General Store Publishing House, Burnstown, Ontario, 196 p., 1995, \$18.95, softcover, ISBN 1896182-30-5.

Lost in the bush, you would be unlikely to starve if you had had the forethought to take a copy of this book with you in your packsack. Mind you, there's a lot more to the book than its potential for succouring the unfortunate traveller in the wilderness.

Dr. Gaertner holds a Ph.D. in economic botany and has had a lifetime interest in using edible materials, plant and otherwise, from forest, field, and hedgerow, to supplement the human diet, partly as survival insurance, but also to expand the variety of foods enjoyed and to educate the mind as well as educating the palate. Indeed, many of the recipes are outside the survival repertoire. But all are described with clarity and flair. Ingredients range from mushrooms and saskatoons to muskrats and suckers.

Interwoven through the text are comments and anecdotes that add much to the depth and charm of the book. Many of the asides supply touches of humour in just the right amount, e.g., "Rattles at the end of a snake's tail identify it as a rattler. The number increases with age of the snake. A better distinguishing character is the shape of their pupils, vertically elliptical rather than round, compared with other snakes present in Canada. This is important to remember when exchanging meaningful glances...".

The culinary content of the book is entertainingly amplified with relevant biological, sociological, and other background information. Throughout the book, a sprinkling of attractive line drawings, Dr. Gaertner's own, further enhance the text. The quality of the paperback, both typographically and from the standpoint of book production, is unusually high. Reap without Sowing is quite delightful.

\section{R.F. Sutton}

\section{Forest Canopies \\ Margaret D. Lowman and Nalini $M$. Nadkarni, Editors. 1995. Hardback. Academic Press, New York. $624+19$ p. ISBN 0-12-457650-8 (case)}

Forest Canopy is defined as "the more or less continuous cover of branches and foliage formed collectively by the crowns of adjacent trees" (Silvicultural Terms in Canada, For. Can. 1992). It forms an integral part of the forest ecosystem and its study is imperative for sustainable management of the latter. Although interest in canopy research is in infancy and knowledge is scanty and scattered, tremendous efforts are being made to determine and study different components of a forest canopy and their inter-relationships, and determine how a canopy can be managed sustainably in the ecosystem.

This book has been published as a part of the series Physiological Ecology Monographs, and is an excellent compilation of the past and current knowledge on the theories and concepts, methodologies and techniques, and research activities and results in forest canopy investigations. I believe that it will go a long way towards a better understanding of forest canopies. Innumerable new ideas will emanate from this treatise; some will be of practical significance for understanding and management of our ecosystem, others will illuminate aspects of biology which we are not aware of or which we do not understand as yet. It will also increase our curiosity for more knowledge and our appreciation of the natural surroundings. Impetus to this upsurge in interest in canopy biology originated from the increasing concern for environment and biodiversity, and political and economic interests in the conservation of tropical rain forests.

This 624-page compilation has 24 chapters, written by 31 contributors. It is organized in four parts: Part I contains four chapters dealing with the subject of "Structure and Function in Tree Canopies"; Part II contains 12 chapters dealing with the subject of "Organisms in Tree Canopies"; Part III contains four chapters dealing with the subject of "Processes in Tree Canopies"; and Part IV contains four chapters dealing with the subject of "Human Impacts on Canopy Research". Each chapter is a useful synthesis of the available literature on the subject with its own conclusion and summary, and a fairly comprehensive list of references; thus providing a self-contained easily readable and highly informative unit. The quality of the contributions is conssistently high; the writing is generally of a high standard. The language is clear and simple. The book itself is a testament of the interest and extensive research activ- ities devoted to forest canopy globally. It represents a broad range of subject areas, with excellent synthesis of the literature reviewed. Literature citations at the end of each chapter make it easier to refer to specific references while reading a chapter. The sections dealing with the conclusions and recommendations or future prospects at the end of each chapter are particularly useful because they are forward looking both from the point of view research and application. The index at the end allows a fairly easy search for specific areas of interest.

The first chapter deals with "Canopy Access Techniques", a pre-requisite for any canopy research, and discussed in a fair detail with good pictures. Impact of these techniques on ecosystem research, future research directions towards the development of newer techniques, and a conspicuous warning for safety are also included. Chapter 2 deals with "Canopy Architecture in Tropical Trees", and it provides an excellent pictorial approach for architectural models and units. Chapter 3 deals with "Physical Mechanisms of Heat and Mass Exchange between Forests and Atmosphere" and covers discussion of processes that control energy and mass transports within and above forest canopies. Chapter 4 summarizes general pecularities of structure and microclimate of forest canopies as well as include discussion on interactions between various environmental parameters in a canopy atmosphere and canopy organization, and between various forest types. Chapter 5 deals with "Measurement of Arthropod Biodiversity in Tropical Forest Canopy". It discusses how it is imperative to study terrestrial arthropods of forest canopies since they constitute 70 to $97 \%$ of the biodiversity of the planet, and that there is a strong need for collaboration and coordination for various research projects in arthropod biodiversity, particularly for setting up objectives, goals and sampling methods. Chapter 6 discusses the "Ecology and Diversity of Tropical Forest Canopy Ants", particularly their influence at all trophic levels. Chapter 7 deals with "Lizard (Anoline lizard) Ecology in the Canopy of an Island Rain Forest of Puerto Rico", particularly its population and foraging behaviour under different conditions. It also emphasizes the need for similar researches in other tropical forests globe.

Chapter 8 discusses "Canopy Access Techniques and their Importance for the 
Study of Tropical Forest Canopy Birds", and emphasizes the need of research on large canopy birds, which are especially important not only in maintaining biodiversity and ecosystem functions in tropical forests, but also in encouraging ecotourism and preservation of tropical wilderness sites. Chapter 9 deals with Forest Structure and Abundance and Diversity of Neotropical Small Mammals", and Chapter 10 discusses the "Mammals of Rain Forest Canopies", particularly in relation to their morphology, distribution, canopy environment and structure, diet and locomotion, and how the distribution of large mammals is more or less exclusive to tropical rain forests. Chapter 11 deals with general characteristics, paleobotanical history, geographic range and ecology of "Vascular Epiphytes", and their role in ecosystem processes, forest dynamics and global atmosphere. It also emphasizes a distinct need to study their stress physiology and accommodation to unconventional sources of nutrients and moisture supplies. Chapter 12 deals with the "Ecology of Hemi-epiphytes in Forest Canopies" and recommends the need for a systematic work on these plants to understand local endemism, and their role in forest dynamics since they might serve as useful models for physiological examination of changes in resource allocation in response to water relations, nutrient availability, and light, and interactions with their hosts.

Chapter 13 deals with the "Ecology and Population Biology of Mistletoes", and discusses the ecophysiology, host-parasite interactions, mechanism of feeding, ageing, mutualism with birds, canopy access, evolution, and management of this economically important aerial parasite. Chapter 14 discusses "Vines in Tree Tops", their habit and habitat, effect on tree crown and canopy, and their interrelationships with other vines and other canopy creatures. Chapter 15 deals with "Life on the Forest Phyllopane: Hairs, Little Houses, and Myriad Mites". Discussion on mites includes their role as herbivore, predators and scavengers, abundance and diversity in canopy mites and their effect on factors limiting their abundance on leaves and in rain forest canopy in general. Chapter 16 deals with "Nonvascular Epiphytes in Forest Canopies", and includes a discussion on lichens, bryophytes and their population ecology, and role in ecological conservation.
Chapter 17 deals with "Photosynthesis in Forest Canopies" and discusses leaflevel photosynthesis and canopy organization in relation to photosynthesis capacity, canopy level flux measurements, and modeling canopy photosynthesis. Chapter 18 discusses "Herbivory as an Important Component of a Canopy Process in Rain Forest Ecosystem Dynamics", and its impacts on the conservation of forest canopies and implications of herbivory as an ecological process. Chapter 19 deals with "Reproductive Biology and Genetics of Tropical Trees from a Canopy Perspective", and includes the complexities of floral phenology of tropical trees, pollination, sexual systems and mating patterns, fruit and seed dispersal, seedling establishment, and genetic diversity and interaction with a variety of animal and plant species in these forests.

Chapter 20 deals with "Ecological Roles of Epiphytes in Nutrient Cycles of Forest Ecosystems", from the perspective of their history, modeling, storage of nutrients, and inter- and intra-canopy nutrient fluxes. It also emphasizes the need for more research into process-oriented aspects of nutrient cycling, standardization of measurements for canopy nutrient cycling research, and long term studies for epiphytic growth rates, death and decomposition rates, colonization and successful regimes, and for more cooperative studies in different types of forest ecosystems. Chapter 21 deals with "Ethno-botany and Economic Botany of Epiphytes, Lianas, and other HostDependent Plants". Chapter 22 deals with "Collection and Preservation of Plant Material from the Tropical Forest Canopy", including canopy-based methods of collection of plants. Chapter 23 deals with "Tourism, Economics, and the Canopy from the Point of View of a Canopy Biologist", and it includes an interesting view point on the role of tourism both as a useful and detrimental factor to the sustainability of canopy forests. Chapter 24 summarizes the present state of knowledge on the subject of forest canopy, and discusses forest canopy as a science and its role in research, education and preservation of forest ecosystem.

The quality of photographs and diagrams is superior with good, although sometimes lengthy, captions. I believe that a few good quality colour photographs and a few more black and white pictures would have enhanced the presentations and discussion on structures and characteristics given in this publication.

This book, although first on the subject, is an excellent initiative. It is not by any means comprehensive. There are some obvious gaps, such as microbial ecology, including distribution and role of fungi, both as saprophytes and pathogens, in forest canopy and forest dynamics in general, nutrient cycling, food and carbon chain in forests. Although herbivores have been discussed, the part played by insect pests and other pathogens, which are extremely important in forest dynamics, has been overlooked. Similarly the role of bats and discussion on the subject of evolutionary aspects of diversity of organisms have been somehow missed. On the whole, the treatise does an excellent job of putting together most of the current knowledge on the subject as well as analyzing what needs to be done. There are a few articles which tend to be more general than scientific.

This book will lead to a better appreciation of forest canopies and a better understanding of their role in sustainable management of forest ecosystem. It will stimulate continued interest in the subject and promote greater awareness of the need for further research on forest canopies. The possibilities for such research are endless.

This book will serve as fascinating reading and a useful source of well summarized information, which will be of great interest to foresters, botanists, forest managers, zoologists, ecologists, environmentalists, and students of biology in general and forestry in particular in research institutes, universities, government organizations, libraries, and non-government agencies.

I recommend this publication to student and professionals dealing with plants, animals, forests and ecosystems, and those interested in the care, sustainability and management of forests and forest ecosystems.

\section{Pritam Singh \\ Science and Sustainable Development Directorate, CFS, Ottawa}

\section{Comparing Environmental Risks: Tools for Setting Government Priorities \\ J. Clarence Davies, Editor. 1996. VI+ $157 \mathrm{pp}$. Resources for the Future, Washington, DC. ISBN 0-915707-79-9.}

The papers presented in this slim volume had their origins in a workshop 
organized by Resources For the Future's Center for Risk Management in response to a request from the President of the United States' Office of Science and Technology Policy. The papers outline the origins of Comparative Risk Analysis (CRA) for assessing environmental risks and its evolving terminology and methods. The application of CRA to environmental issues at the State and Federal levels in the United States is discussed at some length and the book ends with two chapters on refining the technique and a proposal for using it in federal agencies for ranking risk.

The basic technique is a common sense approach of developing a list of problems, devising a set of criteria for evaluating the problems, ranking them as regards seriousness or priority for action and finally preparing an action plan. Nothing very novel about that. What is perhaps more novel is that the proponents of CRA go beyond this simple description and see CRA as a way of communicating with the public and stake holders generally on environmental issues and involving them in formulating decisions on these issues. The applications described are essentially "small p political" exercises with public and interest group involvement.

I was surprised to learn that many in the environmental movement oppose the use of CRA and prefer a straight ban on toxic compounds for example. This is partly because CRA was used early on in justifying nuclear power developments and thus remains "tainted" but also because they see it as a means to delay action on perceived environmental hazards. Compared to Canada, the United States makes much more use of specific legislation to mandate an agency to do certain things and only those things or to ban the use of or set limits on the use of specific substances. Many environmental activists seem to prefer this approach over one like CRA because decisions are probably more easily influenced by direct lobbying of law makers.

I found this volume on CRA interesting, not for its details on the technical aspects of the method which are really relatively simple although there is still a lot of room to reduce the uncertainty factors. Rather my interest was caught by the discussion of how CRA is being put to use in the public and political arenas. That is where it seems to be developing potential, particularly in the United States, for bringing about a better apportioning of scarce resources to deal with environmental problems that are serious risks in the eyes of a broad range of stakeholders and the public.

\section{A Comparative Review of the Forest Practices Code of British Columbia} with Fourteen other Jurisdictions Background and Summary Report Prepared by Westland Resource Group for the British Columbia Ministry of Forests, 1995. Crown Publications Inc., Victoria, BC, 270 pp. and 53 pp. \$21 and $\$ 5$.

These two publications compare the forest practices of British Columbia to those of 14 other jurisdictions. Jurisdictions that are compared are Ontario, Nova Scotia. United Kingdom, Germany, Sweden, Finland, Region 6 of the United States, Alaska, Oregon, Washington State, California, Tasmania, Victoria, and Western Australia. Two main topics are compared; the legal and administrative settings, and the forest practices. Information for the areas was obtained by a review of the literature and questionnaires sent to the jurisdictions examined. Each jurisdiction reviewed the final report for their area.

The detailed, but concise reports provide the reader with an easy opportunity to become familiar with the up-todate forest management practices of the 15 areas. Without these reports, an individual would have to spend a considerable amount of time to collect the information. They will also be useful for students who wish to learn the variety of forest management practices that a forester may have to deal with.

A winner for the best forest management practices is not picked by the report nor are the regulatory practices of the jurisdictions evaluated. In the Summary Report, it is pointed out that the comparisons do raise some questions. They provide examples concerning the variation in the maximum clearcut size and the different widths of riparian and stream side management areas. Readers will probably have other questions stimulated by reading the information.

In the Summary Report, the information of the Background Report is condensed into tables and figures. This information could have been easily included with the Background Report. Unfortunately there are some errors in the summary. Figure 6 has the total harvest area per year
1000 times larger than it should be. Table 1 lists the annual timber harvest in hectares rather than cubic metres. These errors do not detract from the value of the reports in providing information on current management practices. Hopefully the reports will lead to the evaluation of the most variable practices and to improved management procedures.

C. A. Benson

\section{Dictionary of Natural Resource Management}

Julian Dunster and Katherine Dunster, University of British Columbia Press, Vancouver, BC. 363 pp.

The field of natural resource management is expanding, attracting individuals and ideas from a wide array of disciplines. For effective communication to take place, it is increasingly important to know the exact meanings attached to terms used. The Dictionary of Natural Resource Management addresses this need and provides a single source of definitions for natural resource management terms. With its more than 6,000 entries, many of them illustrated, and a detailed set of appendixes covering the classification of organisms, geological time scales, and conversion factors, it is the most up-to-date and comprehensive reference work of its kind available.

Dictionary of Natural Resource Management encompasses terminology from a wide array of disciplines, including forestry, landscape ecology, fish and wildlife management, mycology, forest fire control, pedology, resource planning, sustainable management, conservation biology, silviculture, pest management, botany, conflict resolution, geology, geomorphology, and engineering and harvesting.

Clear definitions, along with the multiple meanings that some terms now have, are provided for each entry. These have been derived from the authors' extensive review of contemporary literature and glossaries, and from discussions with experts around the world. By enabling readers to better understand and effectively use technical terms, the Dictionary of Natural Resource Management will become an essential reference work for resource managers, planners, resource lawyers, students, decisionmakers, and anyone else involved in any aspect of managing the planet's natural resources.

Publisher's Jacket Summary 